\title{
Brexit and India-EU Free Trade Agreement
}

\author{
Amrita Roy \\ Indian Institute of Technology Kanpur, India \\ Somesh K. Mathur \\ Indian Institute of Technology Kanpur, India
}

\begin{abstract}
India and the European Union are in the negotiation process for a Free Trade Agreement. However, as the result of a vote on June 23, 2016, the United Kingdom decided to exit from the European Union, i.e., Brexit. Consequently, bilateral trade costs between the United Kingdom and the European Union will increase both from the newly applicable tariff and non-tariff barriers, which will have a direct impact on trade flows between these two trading partners and an indirect impact on their income growth and on their trading partners. The United Kingdom has been is the most important trading partner for India in the EU, thus the trade deal would not be as beneficial for India as it would have been were the United Kingdom still a member of the European Union. This study attempts to analyze the effects of trade liberalization on the bilateral trade structure between India and the European Union, and the welfare effects both considering the United Kingdom as a member of the European Union and the situation when the United Kingdom exits the European Union. The study found that when United Kingdom is a member of the European Union, both India and the European Union gain more than the situation when the United Kingdom exits the European Union; due to Brexit, India

\footnotetext{
* Corresponding Author: Somesh K. Mathur; Department of Humanities and Social Sciences, IIT Kanpur, Kanpur-208016(UP), India, Phone: +91-5122597155(office), Email: skmathur@iitk.ac.in

Co-authors: Amrita Roy; Department of Humanities and Social Sciences, IIT Kanpur, Kanpur-208016 (UP), India, Email: amritaroy.29@, gmail.com.
} 
would experience the decline of GDP growth rate from 1.1 to 0.5 percent while the European Union, from 0.1 to -0.5 percent.

\author{
JEL Classifications: F13, F14
}

Keywords: Free Trade Agreement, GTAP, Brexit, Trade Policy

\title{
I. Introduction
}

The European Union (EU), including the United Kingdom (UK) is the most important trading partner of India. According to the European Commission (2016), the value of EU-India trade grew from 28.6 billion euros in 2003 to 72.5 billion euros in 2014 and EU investment stock in India was 34.7 billion euros in 2013. At the same time, India is emerging as a global economic power and a growing market of more than 1 billion people. Because of the growing importance of each other as trade partners, India and the EU initiated negotiations for a Free Trade Agreement (FTA) in 2007. So far, most of India's trade negotiations have remained within Asia and, for the EU, trade negotiations have been conducted mostly with its neighboring countries. This IndiaEU FTA is different from other trade negotiations, especially for India, because of the considerable difference between these two economic units with respect to their economic developments. Therefore, it is very important to assess the possible economic and welfare effects from the complete removal of all trade impediments with respect to their own economies and their major trading partners, which are not a part of this agreement.

As the result of a vote on June 23, 2016, the UK decided to exit the EU. Though the legal process of the withdrawal of the UK from the EU will take time, the immediate effects have started to be felt in these economies, especially in the stock market and in the foreign exchange market via the price of the pound. These reactions in the market are more associated with uncertainty regarding the UK's new policies and regulations and the new international relations that will emerge. All EU members have common trade agreements concerning import tariffs and government regulations. After the withdrawal of the UK from the EU, existing international deals will no longer be applicable for the UK; the UK will also have to submit its own schedule to remain a World Trade Organization (WTO) member. The channels through which Brexit will directly affect 
the UK and EU economies can be considered as trade, migration, and investment. As a result of Brexit, bilateral trade costs between the UK and EU will increase (both from the newly applicable tariff and non-tariff barriers), which will have a direct impact on trade flows among these two trading partners and an indirect impact on income growth and to their trading partners.

Therefore, considering the current situation, if the FTA between the EU (the 27-nation bloc, excluding the UK) and India is implemented, it will have different economic impacts on the negotiating partners compared to the situation when the UK was a member of the EU. If we compare the importance of the UK as a trading partner with the rest of the EU, we find that the UK alone accounted for $22 \%$ of total exports to the EU from India in 2011. Therefore, it is clear that if the EU and India adopt more liberalized trade measures to enhance trade with each other, then the trade deal would not be as beneficial for India as it would have been were the UK still a member of the EU.

This study tries to analyze the effects of trade liberalization on the bilateral trade structure between India and the EU, and the welfare effects of the India-EU FTA, considering the UK as a member of the EU and the situation after the Brexit.

The rest of the paper is organized as follows: Section II studies the existing literature and identifies the major issues associated with this India-EU FTA. Section III looks at trade relations between the negotiating countries (India and the EU) and the UK. In Section IV, we present a quantitative analysis of the possible effects of trade policy changes resulting from the India-EU FTA. Section V analyzes the simulation results under different scenarios and attempts to find whether the FTA between India and the EU is still beneficial after the Brexit; finally, Section VI concludes.

\section{Literature Review}

India and the EU member states have shared very intense diplomatic relations since the early 1960s and their trade relations have improved over time. Although the EU is now India's major trading partner, the relative importance of India to the EU is much less. Alternatively, in terms of various indicators of economic development, these two trading partners are significantly different from each other.

The inability of both parties to reach consensus on several issues has obstructed 
finalization of the FTA. Several questions have been raised regarding the impact of the India-EU FTA for some specific sectors (e.g., dairy, textiles, beverages, and automobiles). Since import duties from the EU are relatively high for these products in India, the elimination or significant reduction of import tariffs is suspected to affect these sectors to a large extent. Again, the Brexit decision has added new questions to the already existing issue of the benefits derived from the India-EU FTA. In this study, we will assess the macroeconomic and welfare effects of the FTA under these different scenarios.

Some studies, mostly qualitative, have tried to analyze the possible impacts of the India-EU (28-nation bloc) FTA for the two partners and the related countries. Sally (2007) looked at the prospects of the ongoing FTA negotiations between the EU and the Asian partners, India, Association of South-East Asian Nations (ASEAN), and Korea. Ecorosys (2009) has conducted an impact assessment of the India-EU FTA on trade and sustainable development. They report that the FTA, in terms of the reduction or elimination of import tariffs, will bring significant economic gain both in terms of Gross Domesti Product (GDP) and increase in trade flows in India, while the gain for the EU economy from this FTA will be very insignificant in comparison. At the same time, they found that India would gain from expansion of the sectors of wearing apparel, leather, and automotive. The Centre for the Analysis of Regional Integration at Sussex (2007) conducted a qualitative analysis of the potential implications of the FTA between India and the EU. The report noted several opportunities for trade creation between the EU and India.

When analyzing the economic impacts of an FTA, we mostly examine the effect of the negotiated reduction or elimination of import tariffs. Generally, we consider the impact of tariff reduction on tariff revenue, domestic production, trade volume, and consumer gain (represented by welfare and efficiency gain) due to the reduction in import prices. However, a very small reduction in non-tariff barriers might result in a significantly higher impact on the same variables, except tariff revenue. Due to the unavailability of quantitative data with respect to these non-tariff barriers, this very important issue is overlooked when FTA impact assessments are conducted. In this study, along with checking the attractiveness of the FTA currently under negotiation between India and the EU after the Brexit decision, we also try to assess the importance of a liberal trade environment among these trading partners with respect to non-tariff barriers relative to the visible tariff barriers.

In our present world, since countries are highly interconnected, any change in trade 
policy is likely to affect the entire world economy. To take this into account, this study has used the Global Trade Analysis Project (GTAP) as the analytical tool. We analyzed existing trade relations between India and the EU and how these evolved over time while looking at trade patterns between India and the EU, existing applied tariff rates for their trading commodities, and the importance of these two markets for the rest of the world. Based on the countries found to have higher likelihood of being affected by this trade deal, we performed a regional and product aggregation from the GTAP-9 database. Using these aggregations, we ran a number of simulations and identified the trade liberalization conditions that increase the aggregate welfare of these trading partners. We found that a small reduction in non-tariff barriers has wider positive implications for trading partners compared with the overall elimination of the tariff barriers. Comparing the simulation results, we found that the FTA is more beneficial for the trading partners when the UK is within the EU.

\section{Trade and Existing Tariff Structures}

When assessing a proposed FTA between two trading partners, we need to know the importance of each other as trade partners as this indicates their existing trade interdependence. Larger trade volumes also indicate relatively lower trade costs between these two trading partners compared to their other trading partners. In this section, we examine the existing trade relationship between the negotiating parties (India and the EU) to understand the potential channels through which trade policy changes resulting from the FTA will affect both economies.

Looking at the trade patterns between India and the EU, we find that in terms of total trade (exports + imports), the EU (28-nation bloc) is India's largest trading partner. According to the European Commission (EC 2016), the EU accounted for $12.9 \%$ of India's total trade in 2014. In terms of exports, the EU is the largest (16.2\%) and in terms of imports the EU is the second largest (10.6\%) trading partner of India. Figure 1 shows that over the last decade, the EU's trade with India increased in the first half, but declined slightly in the second half. 
Figure 1. EU exports and imports with India

(2007 2015)

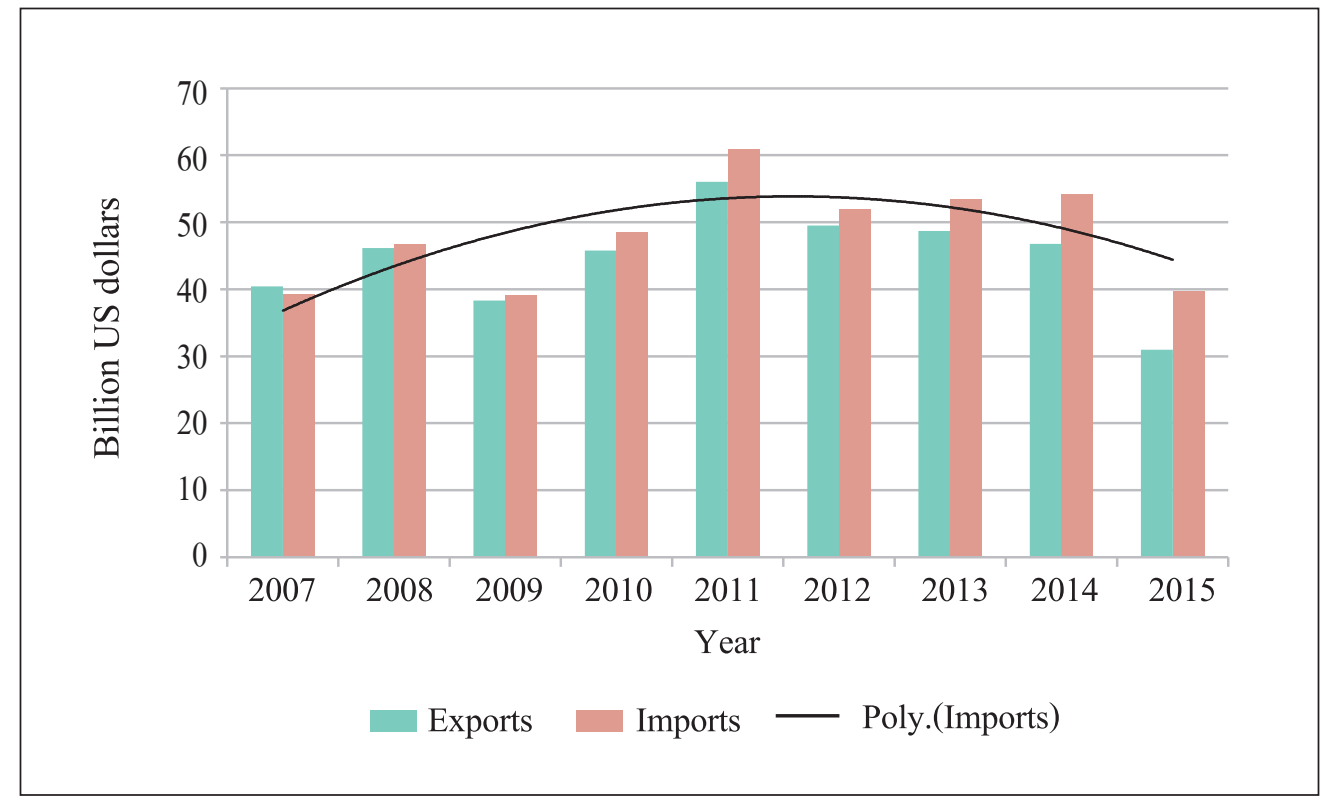

(Notes) i) The vertical axis represents trade values in billion US dollars and the horizontal axis represents the respective years.

ii) Poly. (import) in Figure 1 indicates polynomial trend line (of order 2) of import data.

(Source) COMTRADE (WITS online, accessed on May 18, 2016)

India is relatively less important as a trade partner in terms of total trade share of the EU. In 2015, India accounted for 2.2\% of total trade of the EU. The United States of America (USA) and China account for the maximum share of total trade of EU and India ranks ninth in terms of the EU's trading partners (EC 2016).

\section{A. Trade composition}

Trade composition between the EU and India reveals that industrial products account for more than $90 \%$ of all traded commodities between them. Though agricultural products are important in terms of their share in total EU imports from India, industrial products define almost all exports from the EU to India. 
Table 1. Trade composition of European Union with India

(\% in total imports and exports)

\begin{tabular}{|c|c|c|c|c|c|c|c|c|}
\hline & \multicolumn{4}{|c|}{ Imports } & \multicolumn{5}{c|}{ Exports } \\
\hline Year & $\mathbf{2 0 1 2}$ & $\mathbf{2 0 1 3}$ & $\mathbf{2 0 1 4}$ & $\mathbf{2 0 1 5}$ & $\mathbf{2 0 1 2}$ & $\mathbf{2 0 1 3}$ & $\mathbf{2 0 1 4}$ & $\mathbf{2 0 1 5}$ \\
\hline Agricultural products & 7.5 & 7.5 & 7.5 & 7.6 & 1.2 & 1.3 & 1.5 & 1.9 \\
\hline Fishery products & 1.7 & 1.7 & 2.4 & 2.3 & 0.0 & 0.0 & 0.0 & 0.0 \\
\hline Industrial products & 90.8 & 90.8 & 90.2 & 90.1 & 98.8 & 98.7 & 98.4 & 98.0 \\
\hline
\end{tabular}

(Source) Eurostat Comext (Statistical regime 4, 14.4.2016), from Directorate General for Trade May 19, 2016 (http://trade.ec.europa.eu/doclib/docs/2006/september/tradoc_113390.pdf).

If we look at the structure of exports and imports, we find that in 2014, chemical and rubber products, textiles and wearing apparel, electrical machinery and apparatus, watches and clocks, and medical, precision, and optical instruments were the most important imported commodities from India. Electrical machinery and apparatus, medical, precision, and optical instruments, watches and clocks, mining of metal ores, uranium, gems, other mining and quarrying, and chemical and rubber products were the most important commodities imported to India from the EU. Table 2 reports a summary of the composition of trade between India and the EU according to GTAP product classification (reported in Appendix 1). 
Figure 2. Important traded products of India with the EU

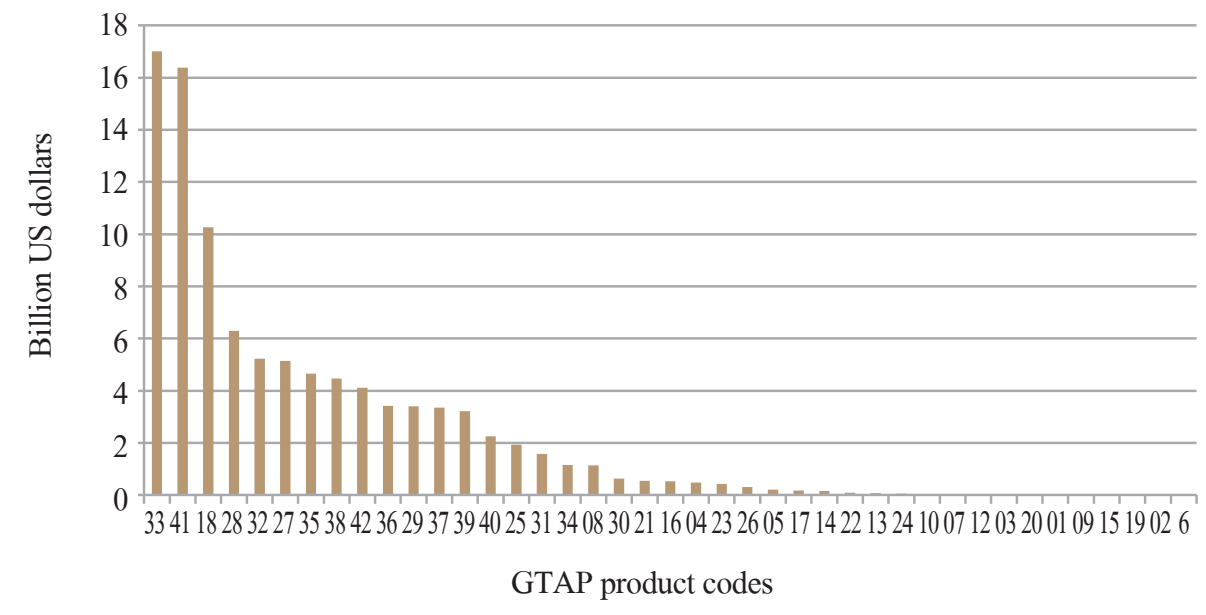

(Notes) (i) The vertical axis represents trade values in billion US dollars and the horizontal axis reports the GTAP product codes (Appendix 2).

(ii) We should also note that in a perfect world, country A reported imports from country B would match with country B reported exports to country A. Consequently, this would make mirroring (using information from the partner when a country does not report its trade) a transparent and error-free process.

(iii) In UN COMTRADE, imports are recorded CIF (Cost Insurance and Freight) while exports are FOB (Free On Board). This may represent a $10 \%$ to $20 \%$ difference. For a given country, imports are usually recorded with more accuracy than exports because imports generally generate tariff revenues while exports do not (WITS manual, p. 38).

(Source) WITS, COMTRADE (accessed online on May 18, 2016)

\section{B. Tariff structure and trade}

Table 2 reports the import tariffs (AD Valorem Equivalent, ADVE) for the GTAP products for India and the EU (for each other's imports) ${ }^{1}$. We see that import tariffs for almost all products are much higher in India compared to those in the EU. Compared to the overall average, import tariffs in India are much lower for the EU products. Tariff

\footnotetext{
' GTAP provides data on applied trade barriers derived from the Market Access Map database. This provides a comprehensive assessment of the protections related to ad valorem tariffs, special tariffs, quotas, etc. that cannot be directly compared or summed and that are not all readily usable in large-scale modeling exercises. To make the database fully operational for analytical purposes, they computed AVEs of each instrument to provide a set of consistent and exhaustive ad valorem equivalents of applied border protection across the world. UNCTAD's Trade Analysis and Information System (TRAINS) and WTO's Integrated Database (IDB) are the alternative sources regarding data on border protection, but the databases differ in coverage and with respect to the methodology.
} 
rates are high in India for agricultural and allied products (paddy, vegetable, oil-seeds, other crops, cattle, forestry, and fishing), processed foods (meat, sugar, vegetable oils, and dairy products), and motor vehicles and parts. The highest tariff rates are applied to beverages and tobacco products. Although average import tariff rates are quite low in the EU compared to India, the EU has relatively higher import protection for processed foods. Therefore, an FTA between these two would imply a more substantial change in the tariff rates in India compared with a very small change in the EU. Consequently, the largest impact will be felt on beverages and tobacco products, and agricultural and allied processed food products sectors in India .

If a significant reduction in import tariff is agreed between India and the EU for each other's products, then a noteworthy portion of import demand in the EU and India from the excluded countries (i.e., excluded from the India-EU FTA) will be replaced by imports from the EU and India. If we assume that supply for the EU imports from India is highly elastic, then this FTA is likely to create significant trade diversion from lowincome developing countries, which are highly dependent on the EU market for their exports.

Table 2. Tariff structure in GTAP products

\begin{tabular}{|l|c|c|c|c|c|}
\hline \multicolumn{1}{|c|}{ Products } & $\begin{array}{c}\text { Import Tariff } \\
\text { for EU } \\
\text { products } \\
\text { in India } \\
\text { (ADV) }\end{array}$ & $\begin{array}{c}\text { Imports } \\
\text { from the EU } \\
\text { in India } \\
\text { (Value 1,000 } \\
\text { US dollars) }\end{array}$ & $\begin{array}{c}\text { Overall } \\
\text { tariff rates } \\
\text { in India } \\
\text { (ADVE) }\end{array}$ & $\begin{array}{c}\text { Import tariff } \\
\text { for Indian } \\
\text { products } \\
\text { in the EU } \\
\text { (ADVE) }\end{array}$ & $\begin{array}{c}\text { Imports } \\
\text { from the EU } \\
\text { in India } \\
\text { (Value 1,000 } \\
\text { US dollars) }\end{array}$ \\
\hline 1 Paddy rice & 80 & 0 & 301 & 3.13 & 2.99 \\
\hline 2 Wheat & 0 & 100 & 9.76 & \\
\hline 3 Other grains & 0.787 & & 26.5 & 11.1 & 528.13 \\
\hline 4 Veg and fruits & 37.3 & 106174.87 & 289 & 1.88 & 205.04 \\
\hline 5 Oil seeds & 22.8 & 1322.4 & 257 & 0 & 617.3 \\
\hline 6 Cane and beet & 0 & & 0 & 3.88 & \\
\hline 7 Plant fibers & 0.756 & 4618.7 & 11.8 & 0 & 7.1 \\
\hline 8 Other crops & 26.3 & 33212.5 & 362 & 1.25 & 20085.2 \\
\hline 9 Cattle & 29.9 & 1.86 & 120 & 0.217 & \\
\hline 10 Other animal \\
products
\end{tabular}




\begin{tabular}{|c|c|c|c|c|c|}
\hline Products & $\begin{array}{l}\text { Import Tariff } \\
\text { for EU } \\
\text { products } \\
\text { in India } \\
\text { (ADVE) }\end{array}$ & $\begin{array}{l}\text { Imports } \\
\text { from the EU } \\
\text { in India } \\
\text { (Value } 1,000 \\
\text { US dollars) }\end{array}$ & $\begin{array}{c}\text { Overall } \\
\text { tariff rates } \\
\text { in India } \\
(\mathrm{ADVE})\end{array}$ & $\begin{array}{l}\text { Import tariff } \\
\text { for Indian } \\
\text { products } \\
\text { in the EU } \\
\text { (ADVE) }\end{array}$ & $\begin{array}{c}\text { Imports } \\
\text { from the } \mathbf{E U} \\
\text { in India } \\
\text { (Value } 1,000 \\
\text { US dollars) }\end{array}$ \\
\hline 11 Raw milk & 0 & & 0 & 0 & \\
\hline $12 \mathrm{Wool}$ & 5 & 14878.40 & 49.6 & 0 & \\
\hline 13 Forestry & 7.82 & 29849.59 & 109 & 1.56 & 50.58 \\
\hline 14 Fishing & 25.7 & 1383.40 & 200 & 4.09 & 18.21 \\
\hline 15 Coal & 3.14 & 65672.43 & 30.5 & 0 & \\
\hline 16 Oil & 0 & 153148.9 & 0.155 & 0 & \\
\hline 17 Gas & 4.99 & & 43.1 & 0 & \\
\hline 18 Other mining & 9.92 & 9080104.52 & 46.3 & 0.025 & 820.25 \\
\hline 19 Cattle meat & 9.48 & 800.42 & 78.9 & 5.73 & \\
\hline 20 Other meat & 23.3 & 2939.95 & 187 & 16.5 & \\
\hline 21 Vegetable oil & 41.4 & 122969.79 & 307 & 0.858 & 5740.38 \\
\hline $\begin{array}{c}22 \text { Milk/dairy } \\
\text { products }\end{array}$ & 41 & 129166.35 & 296 & 14.8 & \\
\hline 23 Processed rice & 0 & 286.16 & 17.7 & 20.9 & 206.28 \\
\hline 24 Sugar & 35.9 & 361.13 & 334 & 20 & 54.24 \\
\hline 25 Other food & 40.6 & 154473.20 & 330 & 5.98 & 2061.0 \\
\hline $\begin{array}{l}26 \text { Beverages and } \\
\text { tobacco products }\end{array}$ & 137 & 175424.38 & 712 & 11.8 & 0.22 \\
\hline 27 Textiles & 8.18 & 395751.13 & 102 & 7.28 & 20486.95 \\
\hline 28 Wearing apparel & 3.56 & 62274.73 & 119 & 8.4 & 21994.15 \\
\hline 29 Leather & 10 & 192351.96 & 81.5 & 2.68 & 11430.42 \\
\hline 30 Lumber & 10 & 277839.05 & 85.3 & 0.058 & 649.62 \\
\hline $\begin{array}{l}31 \text { Paper and paper } \\
\text { products }\end{array}$ & 9.2 & 1214978.32 & 76.8 & 0.004 & 916.59 \\
\hline 32 Petroleum and coke & 5.3 & 398525.07 & 59.4 & 0.001 & 23.73 \\
\hline $\begin{array}{l}33 \text { Chemical and } \\
\text { rubber products }\end{array}$ & 8.16 & 7711094.39 & 71.6 & 0.592 & 57863.6 \\
\hline $\begin{array}{l}34 \text { Non-metallic } \\
\text { minerals }\end{array}$ & 8.69 & 561387.55 & 81.1 & 0.656 & 2061.76 \\
\hline
\end{tabular}




\begin{tabular}{|c|c|c|c|c|c|}
\hline \multicolumn{1}{|c|}{ Products } & $\begin{array}{c}\text { Import Tariff } \\
\text { for EU } \\
\text { products } \\
\text { in India } \\
\text { (ADVE) }\end{array}$ & $\begin{array}{c}\text { Imports } \\
\text { from the EU } \\
\text { in India } \\
\text { (Value 1,000 } \\
\text { US dollars) }\end{array}$ & $\begin{array}{c}\text { Overall } \\
\text { tariff rates } \\
\text { in India } \\
\text { (ADVE) }\end{array}$ & $\begin{array}{c}\text { Import tariff } \\
\text { for Indian } \\
\text { products } \\
\text { in the EU } \\
\text { (ADVE) }\end{array}$ & $\begin{array}{c}\text { Imports } \\
\text { from the EU } \\
\text { in India } \\
\text { (Value } 1,000 \\
\text { US dollars) }\end{array}$ \\
\hline 35 Iron and steel & 5.65 & 3631820.18 & 47.8 & 0.044 & 10222.7 \\
\hline 36 Non-ferrous metals & 8.27 & 5101322.62 & 78 & 1.69 & 223.9 \\
\hline $\begin{array}{c}\text { 37 Fabricated metal } \\
\text { product }\end{array}$ & 9.82 & 1191071.90 & 84.8 & 0.17 & 1913.6 \\
\hline $\begin{array}{c}\text { 38 Motor vehicles } \\
\text { and parts }\end{array}$ & 28.8 & 2373414.42 & 168 & 3.78 & 8834.9 \\
\hline $\begin{array}{c}\text { 39 Other transport } \\
\text { equipment }\end{array}$ & 6.47 & 2667848.66 & 74.2 & 0.39 & 87.85 \\
\hline $\begin{array}{c}\text { 40 Electronic } \\
\text { equipment }\end{array}$ & 1.64 & 2738312.35 & 22 & 0.08 & 1970.42 \\
\hline 41 Other machinery \\
and equipment
\end{tabular}

(Source) GTAP-9 database (import tariffs), WTO IDB (import values)

\section{Impacts of Trade Policy Changes}

\section{A. Global trade analysis project}

The quantitative analysis in this section is based on the simulation results of a computable general equilibrium model of trade based on India and the 28- (and 27-) member bloc EU. The applied general equilibrium model is based on the Global Trade Analysis Project (GTAP) model (originally developed by Hertel, 1997), which is the most widely used computable general equilibrium model to analyze trade policies. The simulation studies estimate the effect of the India-EU FTA on GDP, exports, imports, and the aggregate welfare of the signatory countries and the rest of the world. 
The GTAP model is a multi-sectoral, multi-country applied general equilibrium model. The structure of the GTAP model is based on interrelations between regional production, consumption, and trade. All regional households are interlinked through trade and the global bank. The model incorporates the Armington assumption to deal with bilateral trade, which provides the possibility to distinguish imports by their origin and explains intra-industry trade of similar products. On the supply side, both the factor and product market are assumed to be characterized by perfect competition. The production functions are constant elasticity of substitution functions and are subject to constant returns to scale. Broadly, the primary factors and the intermediate inputs are used to produce output. On the demand side, aggregate income is allocated to the government, households, and savings expenditure using fixed value shares. Private consumption is governed by maximizing the Constant Difference of Elasticity (CDE) objective function. Savings and investment are computed on a global basis and each region contributes a share of its income to the global bank. The single representative regional household maximizes its utility function over private consumption, government consumption, and savings.

In our model, the effect of policy change is reflected in the national accounts aggregates (consumption, investment, government expenditure, and trade), prices and outputs of industrial products, factor inputs and their prices, and trade flows. On the production side with policy changes, the reallocation of factors of production (land, labor, and capital) among sectors results in changes in production efficiency. On the other hand, the demand part is explained by a Cobb-Douglas utility function and total expenditure is allocated among private consumption expenditure, government expenditure, and savings, which maximizes per capita aggregate utility. After a policy shock, the changes in consumption are allocated among these according to their income shares and demand responds related to changes in price and income following the policy shock. On the trade side, a policy shock operates through elasticity of substitution of products based on product differentiation across regions.

In our GTAP model, a trade policy change (e.g., a reduction in import tariff on a particular commodity from any country) will result in a new set of world and domestic prices. This will directly change the trade balance of different countries. Such a price change will affect the production relations associated with the commodity subject to the policy change. Therefore, in this general equilibrium framework, other sectors will also be affected by such changes. The applied general equilibrium models provide analyses of the unobservable equilibria after the policy shocks, which are then compared with 
the level equilibrium observations. In the GTAP model, economic welfare (i.e., regional household equivalent variation) resulting from a policy change is derived from the allocation of national income between private and government consumption and savings. This is calculated as the difference between the expenditure required to obtain a new level of utility at initial prices and initial expenditure.

\section{B. Data}

For the analysis, we have used the latest available GTAP-9 database ${ }^{2}$ and 2011 has been used as the reference year. The GTAP-9 database features 140 regions, which we aggregated into 34 regions. To aggregate the data in GTAP, we first identified the nonsignatory countries which are likely to have a significant negative effect from this trade deal. The following section gives a detailed understanding of the process used to identify the list of probable worst-affected countries by the India-EU FTA.

To identify the probable worst-affected countries, we first listed the countries for which India and the EU are very important with respect to their export destinations. From this set of identified countries, we checked the countries with export structures similar to India's with respect to the EU market. Based on the analyses, we categorized the set of excluded countries most likely to be affected for not being a signatory of the India-EU FTA. We find that a group of African countries and the neighboring Asian countries of India are most likely to experience a negative effect due to the resulting trade diversion effect. We used this set of countries and the GTAP products (all disaggregated available) for our GTAP aggregation to conduct the simulations.

\section{Excluded countries}

Now let us look at how the India-EU FTA might affect countries excluded from the agreement. This mostly happens through the trade diversion effect. Under the India-EU FTA, India and the EU get preferential access to each other's markets, and purchasers from these two partners are likely to switch from other markets to importing from India and the EU. There are several factors that influence the trade diversion effect. For example, with respect to the India-EU FTA, countries highly dependent on their exports to the Indian and EU markets will experience a larger impact for not being signatories

\footnotetext{
${ }^{2}$ https://www.gtap.agecon.purdue.edu/databases
} 
to this agreement. Again, if the export structures of the excluded countries are similar to the composition of the exports of India and the EU to each other's markets, then the excluded countries will feel more competitive pressure as a result of the agreement. Another important determinant of the effect of the FTA on the excluded countries is the negotiation on the extent of tariff reductions.

In Figure 3, we see the importance of the EU and India as export markets for all countries. In 2014, for example, the EU accounted for more than $80 \%$ of total (world) exports for Sao Tome and Principe, Greenland, Cape Verde, Macedonia, and Norway. However, out of the total world exports from India, 16\% went to the EU. Therefore, with respect to the EU's share in total exports, a large number of African, Latin American, and Asian countries are dependent on the EU market for their total exports.

\section{Figure 3. EU's shares in total world exports}

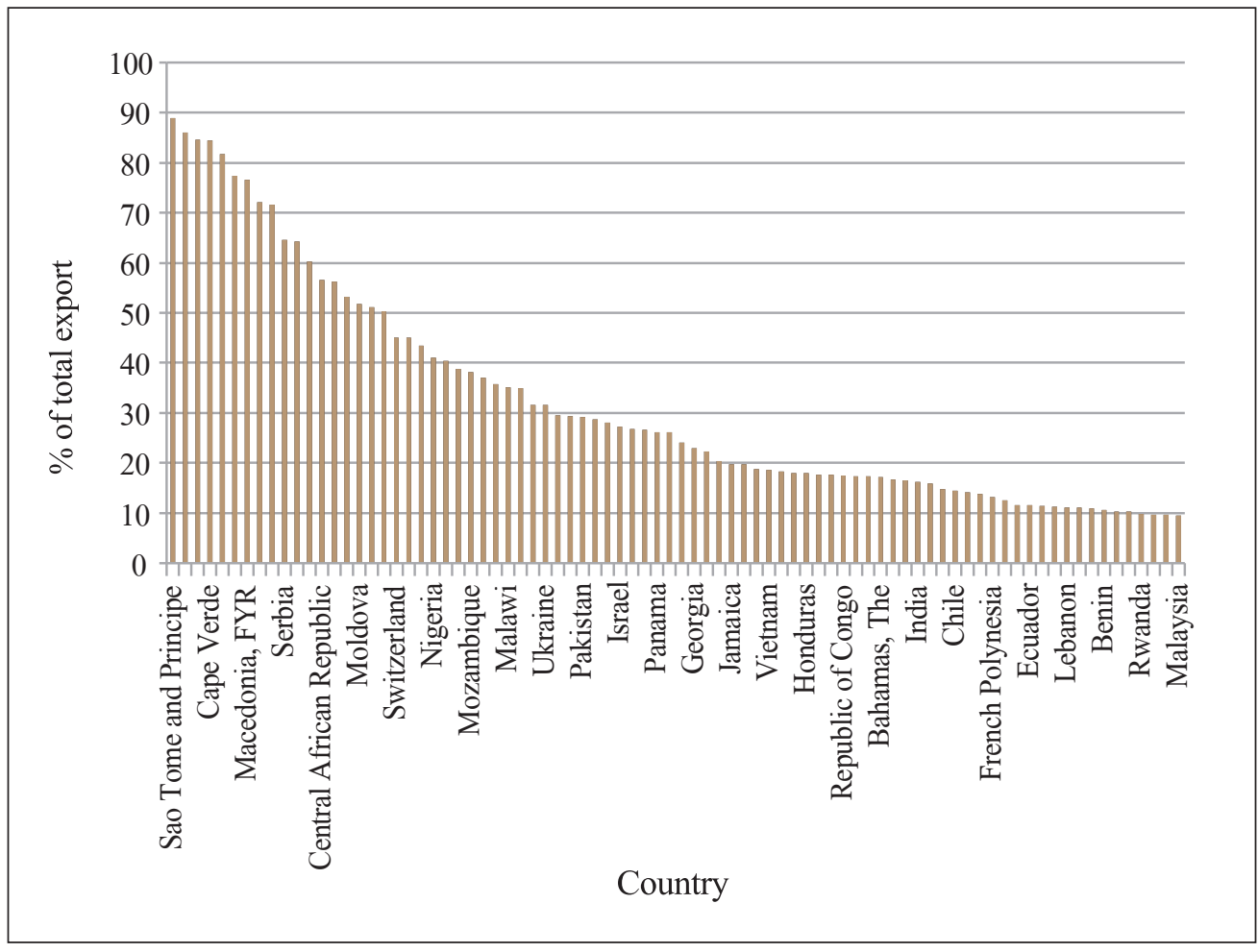

(Note) These shares indicate the percentage of total exports of specific countries that export to the EU market. (Source) COMTRADE (WITS accessed in May 2016) 
Figure 4. India's shares in total world exports

(2014)

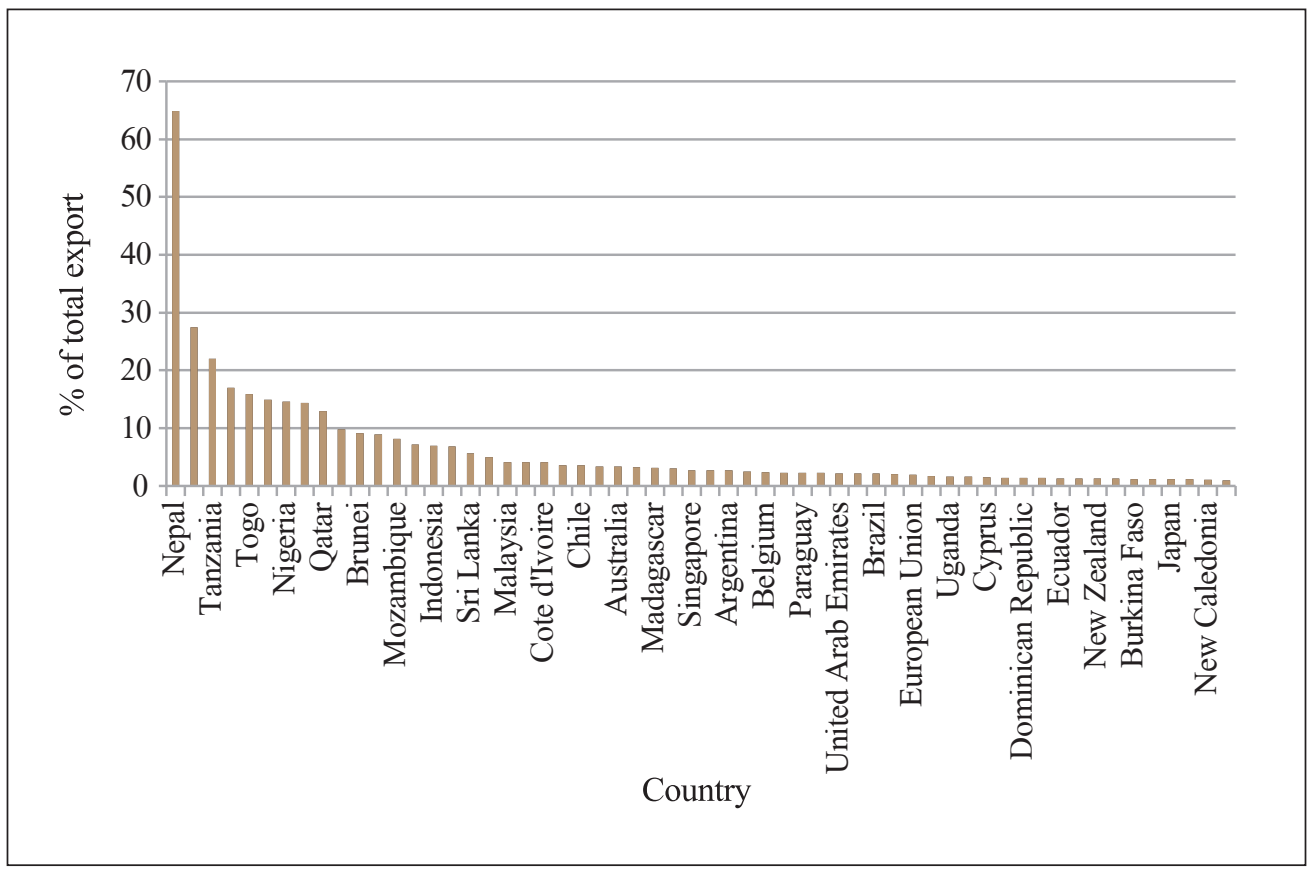

(Note) These shares indicate the percentage of total exports of specific countries that export to the Indian markets.

(Source) COMTRADE (WITS accessed in May 2016)

Regarding the importance of India as an export destination, we find that India's neighboring country Nepal is heavily dependent on the Indian market with respect to its exports. However, the other countries are not that dependent on the Indian market for their exports, India accounts for more than $10 \%$ of total exports for some African countries. At the same time, over the last two decades, India and neighboring South Asian countries have initiated bilateral and regional FTAs. Therefore, a reduction in import tariffs from the EU indicates that these South Asian countries would have to face increased competitive pressure from EU imports in the Indian market.

\section{Export similarity index}

The export similarity (FK) index, developed by Finger and Kreinin (1979), measures the similarity in exports of any two countries to a third market. The index is based on the share of each product in each country's total exports to a third market. The export 
similarity index is then calculated as the sum of the minimum values (shares) for each product for any two countries to a third market. When the export similarity index value is close to one, it suggests that the two countries considered are perfect competitors in the common market.

Table 3. Export similarity index between India and key partners of the EU

(2014)

\begin{tabular}{|l|c|l|c|}
\hline Country/country group & Export similarity & Country/country group & Export similarity \\
\hline Group of African countries & 0.32 & Algeria & 0.15 \\
\hline Albania & 0.29 & Egypt & 0.59 \\
\hline Armenia & 0.24 & Georgia & 0.33 \\
\hline Azerbaijan & 0.04 & Guinea & 0.11 \\
\hline Bosnia and Herzegovina & 0.54 & Hong Kong, China & 0.43 \\
\hline Belarus & 0.39 & Israel & 0.47 \\
\hline Brazil & 0.42 & Japan & 0.38 \\
\hline Botswana & 0.1 & Kazakhstan & 0.11 \\
\hline Switzerland & 0.45 & Sri Lanka & 0.48 \\
\hline China & 0.59 & Non-EU European countries & 0.53 \\
\hline Cote d'Ivoire & 0.26 & Norway & 0.22 \\
\hline Cameroon & 0.14 & Pakistan & 0.37 \\
\hline Ukraine & 0.39 & Russian Federation & 0.24 \\
\hline Vietnam & 0.42 & Turkey & 0.64 \\
\hline
\end{tabular}

(Note) These have been calculated using the GTAP products.

(Source) Our own calculation based on the WITS online data (accessed in July 2016)

Table 3 displays the calculated similarity in exports from India and some important key partners in the EU market (which we have identified in the previous section while examining the market share of EU and India for all the traded countries) across all GTAP product classifications. From the FK index values reported in Table 3, we find that a relatively high degree of similarity exists between exports from India and those from Turkey, China, Egypt, Bosnia and Herzegovina, Sri Lanka, Israel, and the NonEU-European countries (non-EU members) to the EU market. Therefore, it is expected 
that these countries will have to face more competition from Indian exporters in the EU market. Based on these two criteria, we have aggregated 34 regions while noting the (excluded) countries most likely to experience a negative effect for not being signatories of the India-EU FTA (regional aggregations used in our simulations are reported in Appendix 2).

\section{Simulation results when the $\mathrm{UK}$ is a member of the $\mathbf{E U}$}

According to trade theories, the net welfare impact of any regional trade agreement depends on the relative sizes of trade creation and trade diversion effects. Between these two, the first effect is welfare-increasing and the second effect is welfare-decreasing. Trade creation arises when more efficiently produced imported goods replace the relatively inefficiently produced domestic products, thereby increasing import demand due to lower import prices from the partner country. On the other hand, trade diversion occurs when the sources of supply divert from the more efficiently producing nonmember countries to the less efficiently producing member countries under the tarifffree access granted to signatory countries. The final objective of any trade policy is to increase the welfare of the signatory nations. The result of the implementation of an FTA is a new tariff structure and a new assemblage of prices. Producers and consumers respond to these changes by choosing a different bundle of commodities and, thus, welfare also changes.

In the GTAP model, the behavior of a representative household is characterized by a utility function that is governed by private household consumption, government consumption, and savings. The percentage change in the aggregate per capita utility in a region resulting from a simulation of the GTAP model represents the change in welfare of that region. The model computes the money metric equivalent of this utility in US dollar and is referred to as equivalent variation.

Table 4 summarizes the regional welfare changes resulting from the policy shock. For the purpose of the study, we used two policy shocks:

1. Complete removal of import tariffs on all traded commodities for both trading partners.

2. Complete removal of import tariffs and export taxes/subsidies on all traded commodities for both trading partners. 
We find that both the EU and India experience an increase in welfare due to the removal of import tariffs and export taxes/subsidies from both trading partners for all traded commodities. When only the import tariffs $(t m s)$ are eliminated for both trading partners, in dollar terms, the equivalent variation measure of these welfare changes are 4848.3 million and 1813.4 million for the EU and India, respectively. Similarly, in dollar terms, the equivalent variation measures of these welfare changes are 7378 million and 2678 million for the EU and India, respectively, when both import duties and export taxes ( $t m s$ and $t x s$ ) are eliminated from both trading partners. At the same time, India experiences more than one percent increase in GDP from this policy change. These results indicate that greater policy liberalization for each other's markets leads to a greater increase in welfare for both trading partners.

Considering the non-signatory countries, we find that except for a few countries (Nepal, Benin, Botswana, and Hong Kong), all other regions experience a decrease in welfare when import tariffs are completely eliminated. Again, we also note that the countries whose export patterns to the EU market are quite similar to India's (e.g., Turkey, China, Israel, Egypt, and Sri Lanka) experience a significant decline in welfare.

Table 4. Total welfare effect from policy shocks

\begin{tabular}{|l|c|c|c|}
\hline \multirow{2}{*}{ Country/Group } & \multicolumn{2}{|c|}{ Total welfare effect } & Growth of \\
\cline { 2 - 4 } & $\begin{array}{c}\text { GDP } \\
\text { tariffs }\end{array}$ & $\begin{array}{c}\text { Removing import tariffs } \\
\text { and export taxes/subsidies }\end{array}$ & -0.1 \\
\hline Oceania & -303.4 & -244 & -0.1 \\
\hline North America & -438.1 & -1738 & -0.1 \\
\hline Latin America & -104.7 & -18.7 & 0.1 \\
\hline EU 28 & 4848.3 & 7378 & 0 \\
\hline MENA & -310.7 & 901 & -0.1 \\
\hline SSA & -210.5 & -115 & -0.1 \\
\hline Rest of world & -122.9 & -180 & -0.1 \\
\hline China & -1003.1 & -1928 & 6.4 \\
\hline Nepal & 219.7 & 301 & -0.2 \\
\hline Tanzania & -10 & -17.6 & 0.3 \\
\hline Benin & 16.2 & 13 & \\
\hline
\end{tabular}




\begin{tabular}{|c|c|c|c|}
\hline \multirow[b]{2}{*}{ Country/Group } & \multicolumn{2}{|c|}{ Total welfare effect } & \multirow{2}{*}{$\begin{array}{l}\text { Growth of } \\
\text { GDP }\end{array}$} \\
\hline & $\begin{array}{c}\text { Removing import } \\
\text { tariffs }\end{array}$ & $\begin{array}{c}\text { Removing import tariffs } \\
\text { and export taxes/subsidies }\end{array}$ & \\
\hline Togo & -6.1 & -6.4 & -0.2 \\
\hline Botswana & 8.5 & 5.4 & 0.1 \\
\hline Nigeria & -12 & 111 & 0.1 \\
\hline Russia & -239.2 & -208 & -0.1 \\
\hline Sri Lanka & -61.9 & -126 & -0.6 \\
\hline Pakistan & -56.2 & -81.4 & -0.2 \\
\hline Vietnam & -51.6 & -87.4 & -0.2 \\
\hline Thailand & -135.9 & -191 & -0.2 \\
\hline Japan & -225.4 & -908 & -0.1 \\
\hline Indonesia & -138.1 & -180 & -0.1 \\
\hline Malaysia & -66.1 & -46.1 & -0.1 \\
\hline Hong Kong & 31.8 & 14.2 & 0 \\
\hline Brazil & -109.3 & -200 & -0.1 \\
\hline Israel & -74.3 & -98.2 & -0.1 \\
\hline Turkey & -136.7 & -242 & -0.1 \\
\hline Egypt & -35.1 & -6.6 & -0.1 \\
\hline Switzerland & -304.9 & -311 & -0.2 \\
\hline Ukraine & -27.9 & -10.8 & -0.1 \\
\hline Belarus & -11.9 & -47.3 & -0.2 \\
\hline Georgia & -0.7 & 0.9 & 0 \\
\hline Rest of Asia & -289.5 & -765 & -0.1 \\
\hline India & 1813.4 & 2678 & 1.1 \\
\hline
\end{tabular}

(Source) Our GTAP simulation results

\section{Brexit and India's FTA with the EU}

The EU works under the principle of a single market, where goods, services, capital, and people are allowed to move freely among the member countries. While removing 
all barriers to the free movement of goods and services benefits the member countries through trade creation, it also expands the market size, increases competition, and allows firms to reap economies of scale. Similarly, the free movement of capital and labor across member countries increases the efficiency with which they are used in production. All these effects work together to reduce domestic prices and increase overall welfare. However, the main disadvantage for EU members under the single market principle is that the members lose their sovereignty to frame their own rules and regulations based on their priority and their sensitive areas. Therefore, it is expected that with the decision to exit the EU, the UK will face several losses related to market access and efficiency loss related to production.

The EU (27) is the largest trading partner of the UK; thus, by being a member of the EU, the UK could reap the benefit of lower trade costs with the EU. Busch and Matthes (2016) note that the EU is the main trading partner for the British economyit is the destination for around $45 \%$ of all British exports of goods and around $38 \%$ of total exported UK services. Depending on the institutional arrangement between the UK and the EU, Brexit would imply higher EU trade barriers. Trade costs would rise and customs clearance requirements would lead to delays for British firms exporting to the EU.

Studies that have looked into the trade-related impacts of the UK's decision to exit from the EU have mostly tried to analyze the effects on the UK and the EU. Impacts on the rest of the world due to the Brexit are also likely to be felt in the coming years, if not immediately. How this is going to be felt in the rest of the world also depends on how the EU and UK negotiate and initiate new international trade policies.

Before negotiations between the EU and UK take the final shape, we can broadly postulate two potential arrangements:

1. One scenario might arise in which the EU and UK do not reach any preferential agreement with each other; thus, they individually operate as WTO members while maintaining existing relationships with the rest of world. In this situation, the maximum tariff would be the MFN applied tariff rates.

2. In another scenario, we can assume that the EU and UK might keep the import tariffs as low as possible or they might initiate an FTA.

In either situation, it is likely that border movements with respect to all goods, services, and people will be costlier. Even if we assume that reasonable tariff rates are negotiated 
between the EU and the UK, administrative requirements and non-tariff barriers are likely to reduce the importance of each other as a trading partner. Apart from these scenarios, the UK's trade relationships with the rest of the world are also likely to change in the coming years.

\section{Figure 4. Trade trends between the EU and India and the UK and India}

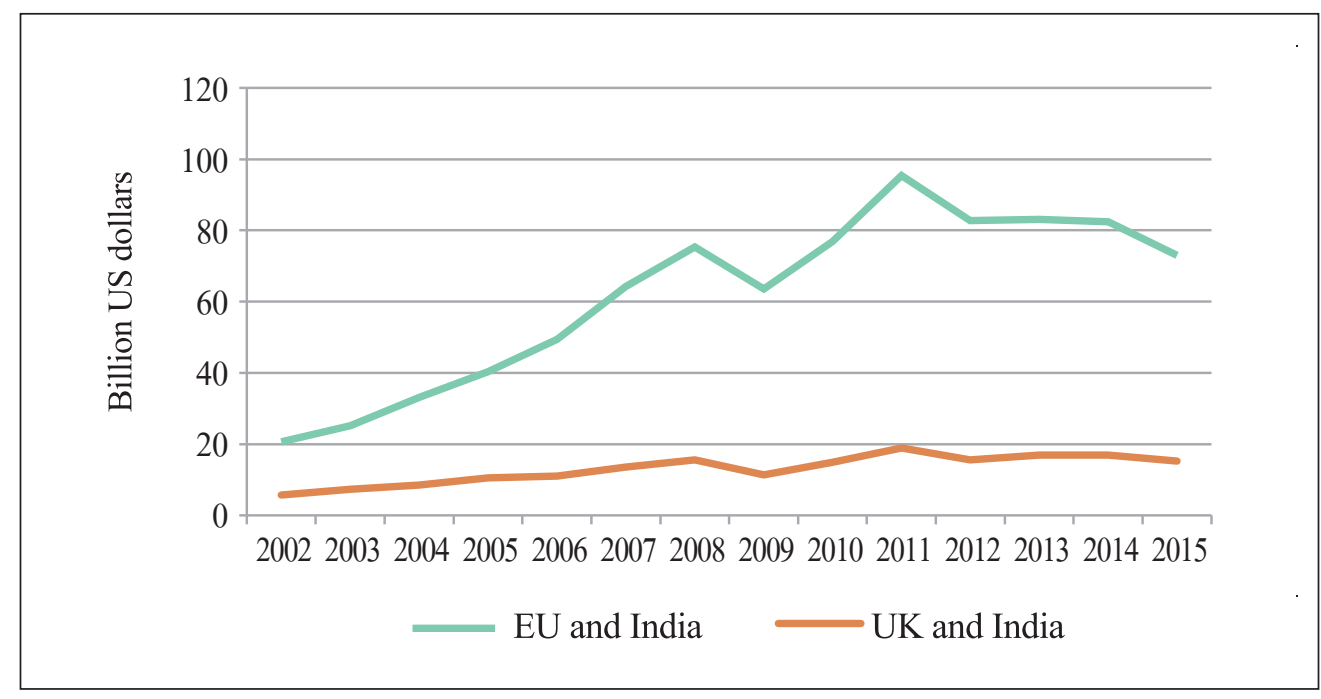

(Note) Total trade (exports + imports) value in billion US dollars on the vertical axis. Horizontal axis reports the corresponding years.

(Source) WITS online database (accessed in August 2016)

If we consider the trade relationship between India and the UK, we find that the UK is the most important export destination for India among the EU members. Among the products exported from India to the UK, textiles, wearing apparel, leather, manufacture of chemical, petroleum, rubber, plastic products and machinery and equipment, and real estate and business activities are very important (Appendix 3). Therefore, it is clear that these sectors will not benefit from the FTA compared with the situation when the UK was a member of the EU. Therefore, we can assume that in the coming years, India would be keen on having more liberal trade policies with the UK.

\section{Simulation results excluding the UK from the EU}

We conducted simulations considering three different arrangements between the EU 
and the UK.

- Scenario I: When the EU and UK negotiate to completely eliminate all trade barriers (import tariff and all non-tariff barriers), i.e., agree to have common standards and regulations.

- Scenario II: They negotiate to be in an FTA (complete elimination of import tariffs), but make border movement $10 \%$ more difficult.

- Scenario III: They work with the WTO applied tariff rates for their imports and make border movement $10 \%$ more difficult.

Table 5. Welfare and growth effects

\begin{tabular}{|c|c|c|c|c|c|c|}
\hline \multirow{2}{*}{ Country/Groups } & \multicolumn{3}{|c|}{ Equivalent variation } & \multicolumn{3}{|c|}{ Growth of GDP } \\
\hline & 1 & 2 & 3 & 1 & 2 & 3 \\
\hline Oceania & -190.9 & 418.4 & 1237.6 & -0.1 & 0.2 & 0.4 \\
\hline North America & -321.8 & 4944 & 9742.3 & 0 & 0.3 & 0.5 \\
\hline Latin America & -60.2 & 768.7 & 1378.0 & 0 & 0.3 & 0.4 \\
\hline EU 27 & 4052 & -33476 & -40415 & 0.1 & -0.3 & -0.5 \\
\hline MENA & -212 & 3436.9 & 4834.0 & -0.1 & 0.3 & 0.4 \\
\hline SSA & -104.8 & 836.9 & 1229.6 & -0.1 & 0.3 & 0.4 \\
\hline Rest of world & -100.5 & 986.9 & 1605.3 & 0 & 0.3 & 0.4 \\
\hline China & -779.6 & 1322.1 & 3382.9 & -0.1 & 0.2 & 0.3 \\
\hline Nepal & 167.4 & -49.5 & -156.0 & 3.3 & -0.8 & -2.7 \\
\hline Tanzania & -4.3 & 7.9 & 16.3 & -0.1 & 0.2 & 0.3 \\
\hline Benin & 11.3 & 3.8 & -7.8 & 0.2 & 0.1 & -0.1 \\
\hline Togo & -4.3 & -3.6 & -4.0 & -0.2 & 0 & 0.1 \\
\hline Botswana & -1.1 & -4.5 & -112.1 & 0 & 0 & -1.9 \\
\hline Nigeria & -7.2 & 316.6 & 428.1 & 0 & 0.4 & 0.5 \\
\hline Russia & -212.5 & 2042.1 & 3300.6 & 0 & 0.4 & 0.6 \\
\hline Sri Lanka & -40.7 & 3 & 21.5 & -0.3 & 0.2 & 0.3 \\
\hline Pakistan & -42.4 & -17.2 & 33.8 & -0.1 & 0.1 & 0.3 \\
\hline Vietnam & -37.7 & 80.4 & 114.4 & -0.1 & 0.3 & 0.4 \\
\hline Thailand & -114.3 & 207.1 & 286.6 & -0.1 & 0.3 & 0.3 \\
\hline
\end{tabular}




\begin{tabular}{|l|c|c|c|c|c|c|}
\hline \multirow{2}{*}{ Country/Groups } & \multicolumn{3}{|c|}{ Equivalent variation } & \multicolumn{3}{c|}{ Growth of GDP } \\
\cline { 2 - 7 } & $\mathbf{1}$ & $\mathbf{2}$ & $\mathbf{3}$ & $\mathbf{1}$ & $\mathbf{2}$ & $\mathbf{3}$ \\
\hline Japan & -186.7 & 430.9 & 1422.4 & -0.1 & 0.2 & 0.4 \\
\hline Indonesia & -105.6 & 129.3 & 436.8 & -0.1 & 0.2 & 0.4 \\
\hline Malaysia & -52.1 & 279.9 & 408.9 & -0.1 & 0.3 & 0.4 \\
\hline Hong Kong & 29.4 & 170.8 & 96.8 & 0 & 0.2 & 0.2 \\
\hline Brazil & -83.1 & 437.2 & 1675.8 & 0 & 0.2 & 0.6 \\
\hline Israel & -61.3 & 269.4 & 479.1 & -0.1 & 0.4 & 0.6 \\
\hline Turkey & -105 & 444.1 & 412.8 & -0.1 & 0.4 & 0.3 \\
\hline Egypt & -25.7 & 184.4 & 270.3 & 0 & 0.4 & 0.5 \\
\hline Switzerland & -183.9 & 847 & 1308.8 & -0.1 & 0.4 & 0.5 \\
\hline Ukraine & -24.3 & 44.4 & 93.7 & 0 & 0.2 & 0.2 \\
\hline-3 Belarus & -10.5 & 7.8 & 27.9 & 0 & 0.2 & 0.2 \\
\hline Georgia & -0.5 & -0.4 & 0.3 & 0 & 0.2 & 0.2 \\
\hline Rest of Asia & -236.9 & 692.6 & 1038.7 & -0.1 & 0.2 & 0.3 \\
\hline India & 1095 & 1028.6 & 3365.5 & 0 & 0.1 & 0.5 \\
\hline UK & -205.6 & -62598 & -84665 & 0 & -4.5 & -7.1 \\
\hline
\end{tabular}

(Notes) (i) 1 indicates scenario I, 2 indicates scenario II, and 3 indicates scenario III. To get the WTO applied tariff rates for the EU and UK we have calculated the average tariff rates applicable for the rest of the world using the GTAP-9 database ${ }^{3}$.

(ii) Policy shock: eliminating import tariffs between India and the EU-27

(Source) Our GTAP simulation results

Table 5 reports the effects of trade policy changes resulting from the India-EU(27) FTA on welfare and growth in GDP in India and the EU under different arrangements. If we compare the different situations when the UK is and is not a part of the EU, we find that even though India benefits from the trade deal, the EU is not able to overcome the loss in welfare from Brexit. It is important to note that the loss in welfare for both the EU

\footnotetext{
${ }^{3}$ To calculate MFN applied tariff rates for the EU and the UK for each other's imports, Ottaviano et al. (2014) and Romagosa (2016) collected data on applied MFN tariff rates by the EU and data on exports and imports for the EU and UK products at each other's markets from the WTO and United Nations (UN) Comtrade databases. Using the trade weights, they calculated the MFN tariffs for both. One problem associated with using these trade data (as weights) is that these data reflect the situation when the UK was a member of the EU and zero tariff rates were applied for each other's imports, which would have been different under the WTO applied MFN tariff rates. Therefore, using the existing trade data as weights might not properly lead us to calculate the MFN applied tariff rates. To overcome this problem, using the GTAP 9 aggregation we have calculated the average tariff rates applied to the rest of the world by the EU and UK. These average tariff rates are then used as the WTO applied tariff rates for the EU and UK for each other's products.
} 
and UK is mainly due to the increase in non-tariff barriers, where even a $10 \%$ increase in non-tariff barriers results in a significant loss in welfare between them. A similar implication is also seen with respect to the growth rates of these economic units. If we consider the case of India, we see that the trade agreement is beneficial for India with respect to welfare and also in terms of growth rates.

Dhingra et al. (2016) noted that the reduction in trade of the UK with its largest trading partner (the EU) would result in a decline in growth rates of around $2.6 \%$. Again, if the decline in the UK's overall productivity is considered to result in a decline in trade with the EU, then the income level in the UK has been estimated to decline by as much as $9 \%$.

Studies have noted that the problem with investment and trade aspect of Brexit issue is the uncertainty associated with the country's relationships with the EU and the rest of the world. In the present context, it is likely, therefore, that the decision to exit from the EU will have significant negative impact in terms of welfare, trade, and growth, but over the coming years, as the situation settles down, these negative effects will subside.

\section{India-EU FTA after Brexit}

From the above analyses, we can assert the following:

- From the viewpoint of overall welfare and growth, the FTA between India and the EU is beneficial for both trading partners. This is true especially for India for both scenarios of UK membership in the EU. However, the extent of gain in welfare and growth depends on the outcome of negotiations between the EU and the UK.

- We also find that when the UK is a member of the EU, India's gain in welfare is greater compared with the situation when it is not. If we study the importance of the UK as an export destination of India compared with the EU-27 (Appendix 3 reports shares of different commodities being exported from India to the UK relative to the exports to the EU from India.), we find that what is being exported to the EU from India, more than one-fourth of that is exported to the UK only. It is clear that the UK has been very important as an export destination among EU members; therefore, the India-EU FTA loses its importance significantly from India's trade 
viewpoint as the most important trading partner of India from the EU disappears from the trade deal.

- Similar to welfare, in case of GDP growth also we find that the FTA between India and the EU (27) is less attractive for both negotiating partners.

- Once the UK exits from the EU, the gain in welfare in the EU generated from the India-EU FTA will marginally offset a part of the loss in welfare in the EU generated by Brexit.

- From all the simulation results, it is clear that the welfare gain and GDP growth resulting from bilateral trade agreements are much more related to the non-tariff barriers compared with agreements related to import tariff reduction. Existing nontariff barriers play the main role in restricting trade flows across countries. Policy makers are generally more bothered about the existing tariff barriers because they are the visible binding constraints in the movement of goods from one country to another.

- Both the EU and the UK lose significantly in terms of welfare and growth after Brexit and the loss is more significant for the UK compared with that for the EU. The increase in regulatory divergence between the EU and UK will lower trade significantly between these two partners and, at the same time, in terms of investments, they will find each other less attractive. The EU operates under a common trade policy; thus, the existing international trade deals of the EU are applicable for all its members. However, once the UK exits the EU, it will initiate independent trade negotiations with the rest of the world. Therefore, although the UK will benefit from its individual trade negotiations, it will not benefit from the EU's forthcoming trade negotiations with the United States, the Transatlantic Trade and Investment Partnership or TTIP, economic partnership agreement with Japan (Dhingra et al. 2016), or the India-EU FTA. Quantifying the macroeconomic effects of the Brexit decision is very difficult since considerable uncertainty issues remain unresolved. Studies that have analyzed the macroeconomic effects of this event are of the view that Brexit is going to have significant negative impact in terms of the macroeconomic indicators in the UK as well as for all the EU members. The actual value or the magnitude of the loss in income levels and welfare that both the UK and the EU will experience in the coming years postBrexit depend entirely on the final negotiations. How the UK reframes its trade relations with the rest of the world post-Brexit will determine the overall loss or gain in income levels for the UK and its new trading partners. 


\section{Conclusions}

India and the EU are currently negotiating a free trade agreement. Although the FTA considers all aspects of trade and investment, in this study, we examined the trade aspect only. We analyzed several possible scenarios where the partners choose to remove or reduce obstacles to their trade. Broadly, these obstacles include tariff and the nontariff barriers associated with the exports and imports of goods and services. For the purpose of the study, we considered cases where the countries take policy initiatives to eliminate their import tariffs and export taxes/subsidies, and improve their export-import technologies to facilitate trade. We have compared the implications of these trade policy changes for situations when the UK is and is not a member of the EU.

Our simulation results indicate that the liberalization of trade is beneficial for both India and the EU. Along with removal of import tariffs, if export taxes/subsidies are also eliminated, then welfare increases for both trading partners. One very important finding to note here is that compared with direct or visible trade liberalization measures such as the removal of tariffs, reduction in non-tariff barriers, or a slight improvement in trade facilitations have a much greater positive impact on welfare.

We have compared the implications of different trade policy changes associated with the FTA between India and the EU for scenarios when the UK is and is not a member of the EU. Our results indicate that in the situation when the UK is a member of the EU, both India's and the EU's gains in terms of welfare from the FTA are greater compared with the situation when the UK is out of the EU. The results do not change when we consider the implications of the FTA on GDP for the negotiating partners. Therefore, it is clear from the results that the FTA between India and the EU loses its importance both for India and the EU when the UK exits the EU.

Received 6 August 2016, Revised 20 October 2016, Accepted 27 October 2016 


\section{References}

Andriamananjara Soamiely, Ferrantino Michael J. and Tsigas Marinos E, "Alternative approaches in estimating the economic effects of non-tariff measures: results from newly quantified measures", OĜCE of Economics Working Paper 2003-12.C, United States International Trade Commission, 2003. https:/www.usitc.gov/publications/332/ ec200312c.pdf (accessed April10, 2016)

Busch Berthold, and Matthes Jürgen, "Brexit - The Economic Impact A MetaAnalysis", IW Report 10/2016, Cologne Institute for Economic Research, 2016 http:// www.iwkoeln.de/studien/iw-reports/beitrag/berthold-busch-juergen-matthes-brexit-theeconomic-impact-277405 (accessed September 2, 2016)

Dhingra Swati, Ottaviano Gianmarco, Sampson Thomas and Reenen John Van, "The consequences of Brexit for UK trade and living standards", Paper Brexit 02, Centre for Economic Performance, London School of Economics and Political Science, UK, 2015. http://cep.lse.ac.uk/pubs/download/brexit02.pdf (accessed July 4, 2016)

European Commission, "Trade Sustainability Impact Assessment for the FTA between the EU and the Republic of India", Final Report, TRADE07/C1/C01 - Lot 1, 2009. http://trade.ec.europa.eu/doclib/docs/2009/june/tradoc_143372.pdf (Accessed May 20, 2016)

European Commission, 2016. https://ec.europa.eu (accessed June 10, 2016)

Finger J. M. and Kreinin M.E, "A Measure of 'Export Similarity' and Its Possible Uses," Economic Journal 89 (1979): 905-912.

Fox Alan K., Francois Joseph F., and Lonono-Kent Pilar, "Measuring Border Crossing Costs and Their Impact on Trade Flows: The United Sates-Mexican Trucking Case." (Paper Presented at the 6th Annual Conference on Global Economic Analysis, 2003). (http://citeseerx.ist.psu.edu/viewdoc/download?doi=10.1.1.561.527\&rep=rep1\&type=p df) (accessed February 2, 2016).

Fugazza Marco and Maur Jean-Christophe, "Non-tariff Barriers in Computable General Equilibrium Modelling", Policy Issues in International Trade and Commodities Study Series No. 38, United Nations Conference on Trade and Development, United Nations, New York and Geneva 2008. http://unctad.org/en/Docs/itcdtab39_en.pdf (accessed March 10, 2016). 
Gasiorek Michael, Holmes Peter, Robinson Sherman, Rollo Jim and Shingal Anirudh, "Qualitative analysis of a potential Free Trade Agreement between the European Union and India", Main Report, Centre for the Analysis of Regional Integration at Sussex and CUTS International, 2006. http://trade.ec.europa.eu/doclib/docs/2007/june/ tradoc_135101.pdf(Accessed March 4, 2016)

Global Trade Analysis Project, Purdue University, GTAP9 database. https://www.gtap. agecon.purdue.edu/databases/v9 (accessed June 10, July 4, 2016).

Hertel Thomas W., ed., Global Trade Analysis: Modeling and Applications (Cambridge: Cambridge University Press, 1997).

Hertel Thomas W., Walmsley Terrie and Itakura Ken, Dynamic effects of the "new age" free trade agreement between Japan and Singapore. Journal of Economic Integration, 16 (2001): 446-484. https://doi.org/10.11130/jei.2001.16.4.446 (accessed March 10).

Kee Hiau Looi, Nicita Alessandro and Olarreaga Marcelo, "Estimating trade restrictiveness indices". CEPR Discussion Paper 5576 (2006). https://papers.ssrn.com/ sol3/papers.cfm?abstract_id=912678 (accessed June 5, 2016).

Ottaviano Gianmarco, Pessoa Joao Paulo, Sampson Thomas and Reenen John Van, "The Costs and Benefits of Leaving the EU", CFS Working Paper 472 (2014), Center for Financial Studies, Goethe University Frankfurt.

Ramagosa Hugo Rojas, "Trade Effects of Brexit for the Netherlands", CPB Background document (2016). http://www.cpb.nl/sites/default/files/omnidownload/CPB-BackgroudDocument-June-2016-Trade-effects-of-brexit-for-the-netherlands.pdf (accessed September 20, 2016)

S. J. D. Nimnual Piewthongngam and Vijitnopparat Prasert, "Trade Facilitation Cost of non- cooperation to consumers in the ASEAN economic community", The Asian Foundation (2014).http://www.asiafoundation.org/resources/pdfs/TradeFacilitationCost ofNonCooperationtoConsumersintheASEANEconomicCommunity.pdf (accessed June 10, 2016)

Sally By Razeen, “Looking East: The European Union's New FTA Negotiations in Asia”, Number 03/2007 (2007), European Centre for International Political Economy, Belgium. http://www.ecipe.org/app/uploads/2014/12/looking-east-the-europeanunion2019s-new-trade-negotiations-in-asia-1.pdf (accessed June 10, 2016). 


\section{Appendix 1: GTAP products and their corresponding codes}

\begin{tabular}{|c|c|c|}
\hline Number & Code & Description \\
\hline 1 & $p d r$ & Paddy rice: rice, husked and unhusked \\
\hline 2 & wht & Wheat: wheat and maslin \\
\hline 3 & gro & Other grains: maize (corn), barley, rye, oats, other cereals \\
\hline 4 & $v_{-} f$ & Veg \& fruit: vegetables, fruit, nuts, potatoes, cassava, truffles \\
\hline 5 & osd & Oil Seeds: oil seeds and oleaginous fruit; soy beans, copra \\
\hline 6 & $c \_b$ & Cane $\&$ beet: sugar cane and sugar beet \\
\hline 7 & $p f b$ & $\begin{array}{l}\text { Plant fibers: cotton, flax, hemp, sisal, and other raw vegetable materials used in } \\
\text { textiles }\end{array}$ \\
\hline 8 & $o c r$ & $\begin{array}{l}\text { Other crops: live plants; cut flowers and flower buds; flower seeds and fruit seeds; } \\
\text { vegetable seeds, beverage and spice crops, unmanufactured tobacco, cereal straw } \\
\text { and husks, unprepared, whether or not chopped, ground, pressed or in the form } \\
\text { of pellets; swedes, mangolds, fodder roots, hay, lucerne (alfalfa), clover, sainfoin, } \\
\text { forage kale, lupines, vetches, and similar forage products, whether or not in the form } \\
\text { of pellets, plants and parts of plants used primarily in perfumery, in pharmacy, or } \\
\text { for insecticidal, fungicidal or similar purposes, sugar beet seed and seeds of forage } \\
\text { plants, other raw vegetable materials }\end{array}$ \\
\hline 9 & $c t l$ & Cattle: cattle, sheep, goats, horses, asses, mules, and hinnies (and semen thereof) \\
\hline 10 & oap & $\begin{array}{l}\text { Other animal products: swine, poultry and other live animals; eggs, in shell (fresh or } \\
\text { cooked), natural honey, snails (fresh or preserved) except sea snails; frog legs, edible } \\
\text { products of animal origin n.e.c., hides, skins and fur-skins, raw, insect waxes and } \\
\text { spermaceti, whether or not refined or colored }\end{array}$ \\
\hline 11 & $r m k$ & Raw milk \\
\hline 12 & wol & Wool: wool, silk, and other raw animal materials used in textiles \\
\hline 13 & frs & Forestry: forestry, logging, and related service activities \\
\hline 14 & $f_{s h}$ & $\begin{array}{l}\text { Fishing: hunting, trapping, and game propagation, including related service activities: } \\
\text { fishing; fish farms; and service activities incidental to fishing }\end{array}$ \\
\hline 15 & coa & Coal: mining and agglomeration of hard coal, lignite, and peat \\
\hline 16 & oil & $\begin{array}{l}\text { Oil: extraction of crude petroleum and natural gas (part), service activities incidental } \\
\text { to oil and gas extraction, excluding surveying (part) }\end{array}$ \\
\hline 17 & gas & $\begin{array}{l}\text { Gas: extraction of crude petroleum and natural gas (part), service activities incidental } \\
\text { to oil and gas extraction, excluding surveying (part) }\end{array}$ \\
\hline 18 & omn & Other mining: mining of metal ores, uranium, gems, and other mining and quarrying \\
\hline 19 & cmt & $\begin{array}{l}\text { Cattle meat: fresh or chilled meat and edible offal of cattle, sheep, goats, horses, } \\
\text { asses, mules, and hinnies; raw fats or grease from any animal or bird }\end{array}$ \\
\hline 20 & omt & $\begin{array}{l}\text { Other meat: pig meat and offal; preserves and preparations of meat, meat offal, or } \\
\text { blood; flours, meals, and pellets of meat or inedible meat offal; greaves }\end{array}$ \\
\hline
\end{tabular}




\begin{tabular}{|c|c|c|}
\hline Number & Code & Description \\
\hline 21 & vol & $\begin{array}{l}\text { Vegetable oils: crude and refined oils of soya-bean, maize (corn), olive, sesame, } \\
\text { ground-nut, olive, sunflower seed, safflower, cotton seed, rape, colza and canola, } \\
\text { mustard, coconut palm, palm kernel, castor, tung jojoba, babassu, and linseed, } \\
\text { perhaps partly or wholly hydrogenated, inter-esterified, re-esterified or elaidinized; } \\
\text { margarine and similar preparations, animal or vegetable waxes, fats and oils and their } \\
\text { fractions, cotton linters, oil-cake and other solid residues resulting from the extraction } \\
\text { of vegetable fats or oils; flours and meals of oil seeds or oleaginous fruits, except } \\
\text { those of mustard; degras and other residues resulting from the treatment of fatty } \\
\text { substances or animal or vegetable waxes }\end{array}$ \\
\hline 22 & mil & Milk: dairy products \\
\hline 23 & pcr & Processed rice: rice, semi- or wholly milled \\
\hline 24 & $\operatorname{sgr}$ & Sugar \\
\hline 25 & ofd & $\begin{array}{l}\text { Other food: prepared and preserved fish or vegetables; fruit juices and vegetable } \\
\text { juices; prepared and preserved fruit and nuts; all cereal flours, groats, meal and } \\
\text { pellets of wheat, cereal groats, meal and pellets n.e.c., other cereal grain products } \\
\text { (including corn flakes), other vegetable flours and meals; mixes and doughs for the } \\
\text { preparation of bakers' wares; starches and starch products; sugars and sugar syrups } \\
\text { n.e.c.; preparations used in animal feeding, bakery products, cocoa, chocolate, and } \\
\text { sugar confectionery; macaroni, noodles, couscous, and similar farinaceous products; } \\
\text { food products n.e.c. }\end{array}$ \\
\hline 26 & $b \_t$ & Beverages and tobacco products \\
\hline 27 & $\operatorname{tex}$ & Textiles: textiles and man-made fibers \\
\hline 28 & wap & Wearing apparel: clothing, dressing, and dyeing of fur \\
\hline 29 & lea & $\begin{array}{l}\text { Leather: tanning and dressing of leather; luggage, handbags, saddlery, harnesses, and } \\
\text { footwear }\end{array}$ \\
\hline 30 & lum & $\begin{array}{l}\text { Lumber: wood and products of wood and cork, except furniture; } \\
\text { articles of straw and plaiting materials }\end{array}$ \\
\hline 31 & ppp & $\begin{array}{l}\text { Paper and paper products: includes publishing, printing, and reproduction of recorded } \\
\text { media }\end{array}$ \\
\hline 32 & $p_{-} c$ & $\begin{array}{l}\text { Petroleum and coke: coke oven products; refined petroleum products; processing of } \\
\text { nuclear fuel }\end{array}$ \\
\hline 33 & crp & $\begin{array}{l}\text { Chemical and rubber products: basic chemicals; other chemical products; rubber and } \\
\text { plastics products }\end{array}$ \\
\hline 34 & nmm & Non-metallic minerals: cement, plaster, lime, gravel, concrete \\
\hline 35 & $i s$ & Iron and steel: basic production and casting \\
\hline 36 & $n f m$ & $\begin{array}{l}\text { Non-ferrous metals: production and casting of copper, aluminum, zinc, lead, gold, } \\
\text { and silver }\end{array}$ \\
\hline 37 & fmp & Fabricated metal products: sheet metal products, but not machinery and equipment \\
\hline 38 & $m v h$ & Motor vehicles and parts: cars, trucks, trailers, and semi-trailers \\
\hline
\end{tabular}




\begin{tabular}{|c|c|c|}
\hline Number & Code & Description \\
\hline 39 & otn & Other transport equipment: manufacture of other transport equipment \\
\hline 40 & ele & $\begin{array}{l}\text { Electronic equipment: office; accounting and computing machinery; radio, television, } \\
\text { and communication equipment and apparatus }\end{array}$ \\
\hline 41 & ome & $\begin{array}{l}\text { Other machinery and equipment: electrical machinery and apparatus n.e.c.; medical, } \\
\text { precision, and optical instruments; watches and clocks }\end{array}$ \\
\hline 42 & omf & Other manufacturing: includes recycling \\
\hline 43 & ely & Electricity: production, collection, and distribution \\
\hline 44 & $g d t$ & $\begin{array}{l}\text { Gas distribution: distribution of gaseous fuels through mains; steam and hot water } \\
\text { supply }\end{array}$ \\
\hline 45 & wtr & Water: collection, purification, and distribution \\
\hline 46 & cns & Construction: building houses, factories, offices, and roads \\
\hline 47 & $\operatorname{trd}$ & $\begin{array}{l}\text { Trade: all retail sales; wholesale trade and commission trade; hotels and restaurants; } \\
\text { repairs of motor vehicles; personal and household goods; retail sale of automotive } \\
\text { fuel }\end{array}$ \\
\hline 48 & otp & Other transport: road, rail; pipelines; auxiliary transport activities; travel agencies \\
\hline 49 & $w t p$ & Water transport \\
\hline 50 & atp & Air transport \\
\hline 51 & cmn & Communications: post and telecommunications \\
\hline 52 & $o f i$ & $\begin{array}{l}\text { Other financial intermediation: includes auxiliary activities, but not insurance and } \\
\text { pension funding }\end{array}$ \\
\hline 53 & $i s r$ & Insurance: includes pension funding, except compulsory social security \\
\hline 54 & obs & Other business services: real estate, renting, and business activities \\
\hline 55 & ros & $\begin{array}{l}\text { Recreation and other services: recreational, cultural, and sporting activities; other } \\
\text { service activities; private households with employed persons (servants) }\end{array}$ \\
\hline 56 & osg & $\begin{array}{l}\text { Other services (Government): public administration and defense; compulsory social } \\
\text { security, education, health, and social work; sewage and refuse disposal, sanitation; } \\
\text { and similar activities; activities of membership organizations n.e.c.; extra-territorial } \\
\text { organizations and bodies }\end{array}$ \\
\hline 57 & $d w e$ & Dwellings: ownership of dwellings (imputed rents of houses occupied by owners) \\
\hline
\end{tabular}

(Source) GTAP-9 database 


\section{Appendix 2: GTAP country classifications used for simulations}

\begin{tabular}{|c|c|}
\hline \multicolumn{2}{|c|}{ Country Classification } \\
\hline Oceania & Vietnam \\
\hline North America & Thailand \\
\hline Latin America & Japan \\
\hline EU 27 & Indonesia \\
\hline Middle East and North America (MENA) & Malaysia \\
\hline Sub-Saharan Africa (SSA) & Hong Kong \\
\hline Rest of the World & Brazil \\
\hline China & Israel \\
\hline Nepal & Turkey \\
\hline Tanzania & Egypt \\
\hline Benin & Switzerland \\
\hline Togo & Ukraine \\
\hline Botswana & Belarus \\
\hline Nigeria & Georgia \\
\hline Russia Federation & Rest of Asia \\
\hline Sri Lanka & India \\
\hline Pakistan & United Kingdom (UK) \\
\hline
\end{tabular}




\section{Appendix 3: Export share of the UK relative to the EU-27}

\begin{tabular}{|c|c|c|c|c|}
\hline Products & $\begin{array}{c}\text { Share of exports } \\
\text { from India to UK } \\
\text { relative to EU (27) } \\
(\%)\end{array}$ & $\begin{array}{c}\text { Share of products } \\
\text { in total exports } \\
\text { to the UK from } \\
\text { India }\end{array}$ & $\begin{array}{l}\text { Exports } \\
\text { from } U K \\
\text { to } E U\end{array}$ & $\begin{array}{c}\text { Exports } \\
\text { from } \\
\text { EU to UK }\end{array}$ \\
\hline Paddy rice & 243.9024 & 0.67361 & 5.98 & 31.1 \\
\hline Wheat & 122.1739 & 0.001456 & 373 & 171 \\
\hline Other grains & 49.17492 & 0.015441 & 189 & 279 \\
\hline Veg and fruits & 33.33333 & 0.461164 & 567 & 3877 \\
\hline Oil seeds & 28.95652 & 0.172548 & 369 & 86.3 \\
\hline Cane and beet & 65.65421 & 0.001456 & 1.84 & 3.63 \\
\hline Plant fibers & 7.876448 & 0.002114 & 10.2 & 11.9 \\
\hline Other crops & 21.24863 & 1.005233 & 281 & 1934 \\
\hline Cattle & 73.76426 & 0.001005 & 292 & 330 \\
\hline Other animal products & 20.27027 & 0.03109 & 364 & 448 \\
\hline Raw milk & 73.75887 & 0.053889 & 1.03 & \begin{tabular}{c}
4.7 \\
\hdashline.-
\end{tabular} \\
\hline Wool & 70.2521 & 0.021659 & 25.2 & 31.9 \\
\hline Forestry & 28.42975 & 0.089124 & 67 & 165 \\
\hline Fishing & 37.24832 & 0.028758 & 984 & 375 \\
\hline Coal & 31.57895 & $3.11 \mathrm{E}-05$ & 12.3 & 32.4 \\
\hline Oil & -- & 0 & 10259 & 1187 \\
\hline Gas & 0 & 0 & 2282 & 4360 \\
\hline Other mining & 23.95349 & 1.067413 & 4442 & 700 \\
\hline Cattle meat & 140 & 0.004534 & 1169 & 1412 \\
\hline Other meat & 16.23932 & 0.000985 & 1054 & 6467 \\
\hline Vegetable oil & 6.605744 & 0.131095 & 382 & 1030 \\
\hline Milk/dairy products & 23.9738 & 0.028447 & 1525 & 3973 \\
\hline Processed rice & 24.89083 & 0.088606 & 24.3 & 155 \\
\hline Sugar & 20.86331 & 0.09016 & 348 & 350 \\
\hline Other food & 22.6009 & 1.305767 & 6398 & 14817 \\
\hline Beverages and tobacco products & 35.4 & 0.027514 & 4510 & 6672 \\
\hline Textiles & 20.28886 & 4.58573 & 3415 & 5367 \\
\hline Wearing apparel & 29.81069 & 7.425255 & 2779 & 4953 \\
\hline
\end{tabular}




\begin{tabular}{|c|c|c|c|c|}
\hline Products & $\begin{array}{c}\text { Share of exports } \\
\text { from India to UK } \\
\text { relative to EU (27) } \\
(\%)\end{array}$ & $\begin{array}{c}\text { Share of products } \\
\text { in total exports } \\
\text { to the UK from } \\
\text { India }\end{array}$ & $\begin{array}{c}\text { Exports } \\
\text { from UK } \\
\text { to EU }\end{array}$ & $\begin{array}{c}\text { Exports } \\
\text { from } \\
\text { EU to UK }\end{array}$ \\
\hline Leather & 26.75457 & 3.259236 & 1555 & 3217 \\
\hline Lumber & 26.84211 & 0.343541 & 1125 & 6654 \\
\hline Paper and paper products & 95.10808 & 0.433183 & 5442 & 10121 \\
\hline Petroleum and coke & 9.87954 & 5.694596 & 16076 & 8549 \\
\hline Chemical and rubber products & 20.67129 & 6.63765 & 48338 & 58433 \\
\hline Non-metallic minerals & 20.98951 & 0.725426 & 2042 & 3862 \\
\hline Iron and steel & 6.692913 & 0.616612 & 5487 & 6190 \\
\hline Non-ferrous metals & 15.27473 & 0.144049 & 7511 & 11781 \\
\hline Fabricated metal products & 25.50177 & 2.238458 & 4172 & 8952 \\
\hline Motor vehicles and parts & 25.39474 & 3.000155 & 23942 & 55032 \\
\hline Other transport equipment & 144.0828 & 2.523447 & 8690 & 8463 \\
\hline Electronic equipment & 6.75122 & 0.358568 & 12252 & 17187 \\
\hline Other machinery and equipment & 26.61362 & 4.678999 & 28735 & 45914 \\
\hline $\begin{array}{l}\text { Other manufacturing } \\
\text { (includes recycling) }\end{array}$ & 16.48789 & 2.787709 & 3900 & 5976 \\
\hline Electricity & 28.3737 & 0.004249 & 142 & 725 \\
\hline Gas distribution & 15.88235 & 0.00014 & 454 & 42.9 \\
\hline Water collection, purification & 73.51351 & 0.004228 & 53.6 & 143 \\
\hline Construction & 2.385892 & 0.059589 & 1216 & 1137 \\
\hline Trade & 18.28283 & 0.937872 & 7711 & 8822 \\
\hline Other transport & 61.98347 & 4.663454 & 4098 & 11185 \\
\hline Water transport & 6.538462 & 0.202601 & 1823 & 3573 \\
\hline Air transport & 48.57143 & 0.792787 & 9464 & 15974 \\
\hline Communication & 59.93641 & 1.953469 & 6998 & 6213 \\
\hline Other financial intermediation & 98.34711 & 3.699674 & 24492 & 9508 \\
\hline Insurance & 13.82166 & 0.224882 & 3461 & 2005 \\
\hline Other business services & 46.86903 & 35.60288 & 64174 & 27521 \\
\hline Recreation and other services & 17.03583 & 0.270998 & 6299 & 7872 \\
\hline Other services & 54.26621 & 0.823877 & 3375 & 9245 \\
\hline Dwellings & - & 0 & 0 & 0 \\
\hline Total & 28.13142 & 100 & 345157 & 413522 \\
\hline
\end{tabular}

(Source) GTAP-9 database 